\title{
Early Miocene evolution of the rodent Megacricetodon in Europe and its palaeobiogeographical implications
}

\author{
Adriana Oliver and Pablo Peláez-Campomanes \\ Acta Palaeontologica Polonica 61 (1), 2016: 211-219 doi:http://dx.doi.org/10.4202/app.00099.2014
}

The Megacricetodon material from Aliveri (Isle of Evia, Greece) was previously assigned to $M$. primitivus, implying palaeobiogeographical relationship between south-eastern and south-western Europe. The material from Aliveri is here assigned to the new species Megacricetodon hellenicus sp. nov. This form has significant morphological differences compared to other Early Miocene species from Europe. This new evolutionary hypothesis of this genus has implications on the Early Miocene paleobiogeography of Europe. This work presents a new interpretation on the earliest European representative of the genus Megacricetodon from Aliveri localities. Analyses of the Megacricetodon material from MN 4 and $\mathrm{MN} 5$ localities enable to propose a new palaeobiogeographical framework in which there are three main migration events of the genus Megacricetodon into Europe, each corresponding to different lineages that evolved independently. The new Greek taxon is considered the first migration wave from Anatolia, representing an endemic lineage different from any other European Megacricetodon.

Key words: Mammalia, Rodentia, Cricetodontidae, migrations, endemism, Miocene, Greece.

Adriana Oliver [mcna0831@mncn.csic.es] and Pablo Peláez-Campomanes [mcnp177@mncn.csic.es] (corresponding author), Department of Paleobiology, Museo Nacional de Ciencias Naturales, MNCN-CSIC, C/ José Gutiérrez Abascal, 2. 28006, Madrid, Spain.

This is an open-access article distributed under the terms of the Creative Commons Attribution License (for details please see creativecommons.org), which permits unrestricted use, distribution, and reproduction in any medium, provided the original author and source are credited. 
Farf Full text (448.1 kB) ।

$\mathrm{FOF}_{\mathrm{O}}$ Supplementary file $(982.9 \mathrm{kB})$ 